\title{
Variability of the Water Properties in NAFO Subareas 5 and 6 During the 1990s
}

\author{
David G. Mountain \\ Northeast Fisheries Science Center \\ Woods Hole, MA 02543, USA
}

Mountain, D. G. 2004. Variability of the Water Properties in NAFO Subareas 5 and 6 During the 1990s . J. Northw. Atl. Fish. Sci., 34: 103-112. doi:10.2960/J.v34.m475

\begin{abstract}
The variability in temperature and salinity of the waters on the northeast USA continental shelf and the Gulf of Maine during the 1990s is presented and compared to that during a previous period (1978-87). A general freshening of the surface waters in the Gulf of Maine and of the shelf waters in the Middle Atlantic Bight is documented. An increase in the inflow to the Gulf of Maine of cool, low salinity surface water from the Scotian Shelf during the 1990s was responsible for the freshening. Wintertime warming of the shelf waters in the southern part of the region was noted. The deep waters of the western Gulf of Maine also exhibited a warming during the 1990s. This warming is believed due to reduced winter convective cooling, caused at least in part, by the freshening of the surface layer which increased the stratification that inhibited convection.
\end{abstract}

Key words: Gulf of Maine, Mid-Atlantic Bight, salinity, stratification, temperature

\section{Introduction}

The continental shelf region of the northeast United States from Cape Hatteras northward through the Gulf of Maine (Fig. 1) comprises the coastal portions of NAFO Subareas 5 and 6 . The region is often considered as three separate, but connected areas. The Middle Atlantic Bight is the broad continental shelf region between Cape Hatteras and Cape Cod. Georges Bank is a shallow bank that is, in essence, an eastward extension of the continental shelf and forms the southern boundary to the Gulf of Maine. The Gulf of Maine is a semi-enclosed sea between New England and Nova Scotia with a number of deep $(>200$ $\mathrm{m}$ ) basins. Its only deep connection to the Atlantic Ocean is through the Northeast Channel between Georges Bank and Browns Bank.

The waters in this region come from two primary sources. Relatively cold and low salinity water from the Scotian Shelf enters the Gulf in the surface layers around Cape Sable. Relatively warm and saline water from the offshore slope region enters the Gulf at depth through the Northeast Channel. The properties of the Scotian Shelf Water (SSW) and the Slope Water (SLW) inflows have been described by Smith (1983) and Ramp et al. (1985), respectively. These two inflows progressively mix as they move in a general counterclockwise circulation around the Gulf of Maine to form the Shelf Water (SHW) mass that enters onto the northern flank of Georges Bank. On a temperature-salinity diagram the product of this mixing falls along a line between the two source water masses
(Fig. 2). On Georges Bank, the water moves in a clockwise direction around the eastern end of the Bank and westward along the Bank's southern flank. The majority of the flow continues southwestward into the Middle Atlantic Bight, while a portion of the flow re-circulates around the western end of the Bank. Along the southern flank of Georges Bank and through the Middle Atlantic Bight the boundary between the SHW on the shelf and the offshore SLW occurs in a frontal region, termed the shelf-slope front, that is generally located near the shelf break. The SHW leaves the Middle Atlantic Bight through a number of processes such as wind driven transport, mixing across the shelf-slope front, frontal instabilities, entrainment by Gulf Stream rings and off-shelf flow near Cape Hatteras. The contributions by the different processes however, to the mass balance of the Middle Atlantic Bight are not well documented. The spatial, seasonal and inter-annual patterns in the temperature and salinity of the waters in this region have been discussed in numerous previous reports (Bigelow, 1927; Bigelow and Sears, 1935; Hopkins and Garfield, 1979; Hopkins and Garfield, 1981; Manning, 1990; Brown and Irish, 1993).

The purpose of this paper is to describe the variability in the water properties of the northeast USA Shelf during the 1990s, particularly in relation to conditions during previous decades. Two recent publications have presented extensive information about the water properties in this region during the 1990s, and will be referenced frequently in this analysis. Smith et al. (2001) described conditions in the Gulf of Maine and on Georges Bank during the 


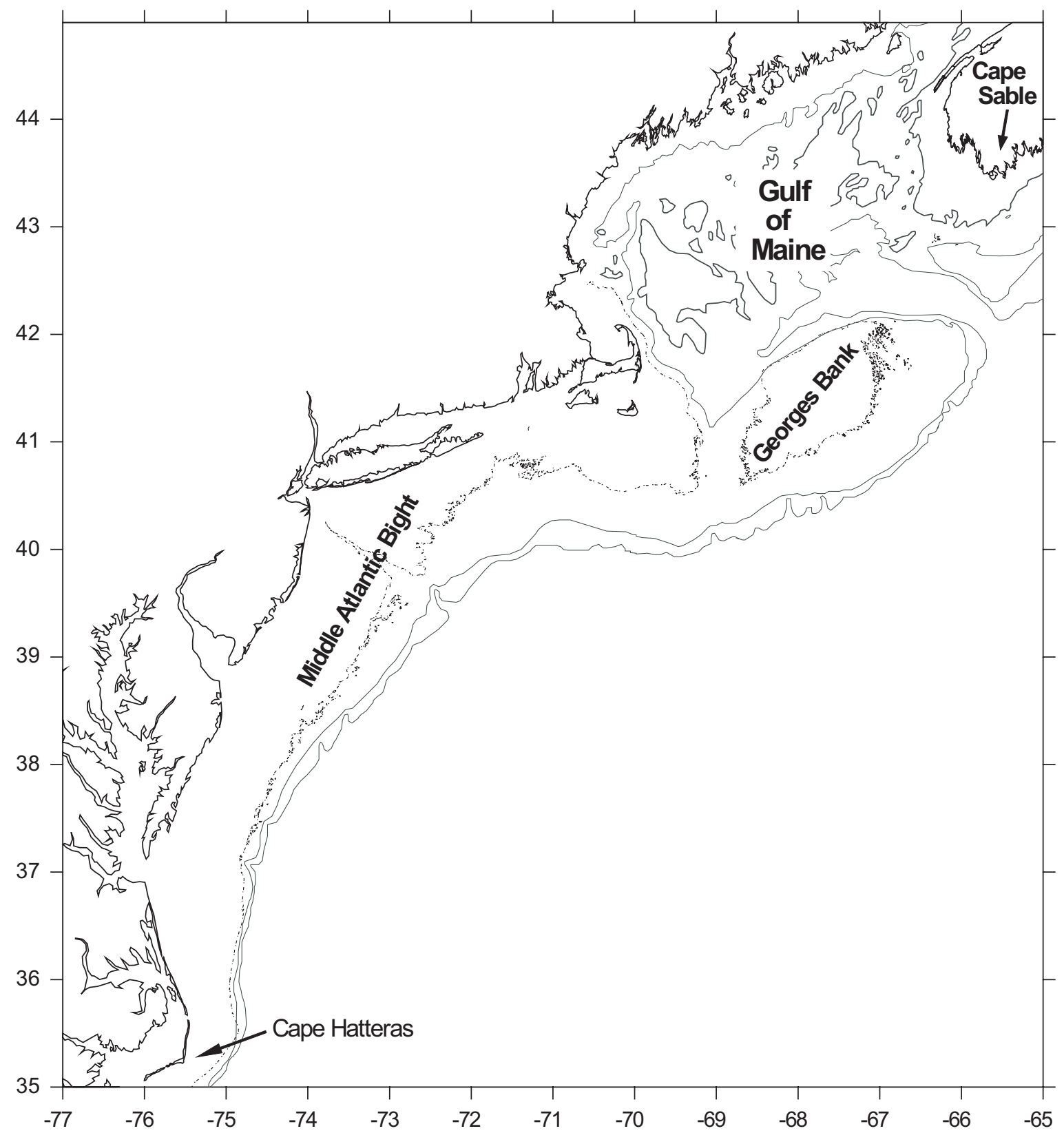

Fig. 1. The northeast USA continental shelf region.

mid-1990s and Mountain (2003) described the variability in shelf water properties in the Middle Atlantic Bight for all of the 1990s.

\section{Data and Methods}

Two hydrographic data sets were used in this analysis. Between 1991 and 1999 hydrographic measurements were made using CTD instruments in some part of the region on over 100 National Marine Fisheries Service (NMFS) surveys. These surveys used a stratified random survey design and were conducted to monitor the distribution and abundance of the fishery resources on the northeast USA continental shelf. The description of conditions during the 1990s is based on these data.

The second data set is from the NMFS Marine Resources Monitoring and Prediction (MARMAP) program that covered the period $1978-87$ and provides a decadal scale comparison with the measurements made 


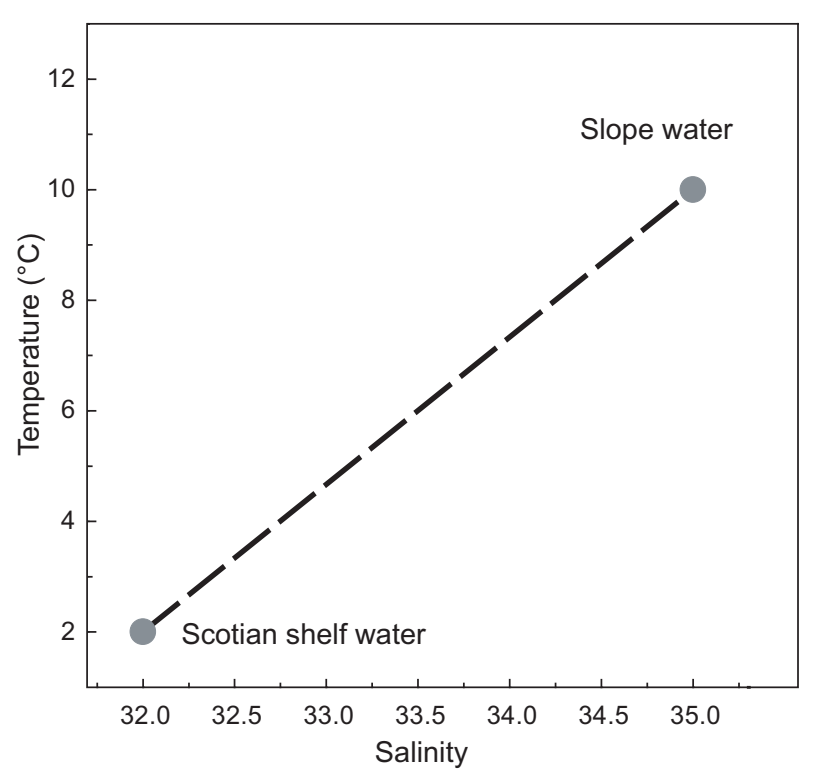

Fig. 2. Temperature/salinity diagram for mixing of the two primary water masses entering the Gulf of Maine: Scotian Shelf Water (SSW) and Slope Water (SLW).

during the 1990s. The MARMAP sampling covered the same shelf region from Cape Hatteras northward through the Gulf of Maine at specific, standard station locations ( $\sim 150$ throughout the region). The hydrographic measurements were made by water bottles and reversing thermometers, except in the last year of the program when a CTD instrument was used. During the ten years of the program, hydrographic measurements were made on 49 survey cruises.

To describe the spatial and temporal variability in water properties, sub-regions of the northeast continental shelf were selected (Fig. 3). Three areas were chosen in the Gulf of Maine to represent the major basins, Georges Basin, Jordan Basin and Wilkinson Basin. For Georges Bank, the northwest portion of the Bank (NWGB) was selected to represent the water entering onto the Bank from the Gulf of Maine. The Middle Atlantic Bight was divided in to five sub-regions, following Mountain (2003).

For the areas in the Gulf of Maine the volume averaged temperature and salinity were determined for each survey in both data sets for the surface layer (0-30 $\mathrm{m}$ depth) and for a layer near the bottom (150-200 m depth). The method used for spatial averaging of the observations on a survey is described in Mountain (2003). The average calendar day of the observations used in the averaging for each survey also was determined. Similar calculations were done for the surface layer in the NWGB region. In the Middle Atlantic Bight the properties of the shelf water were determined for each area on each survey, again following the methods used by Mountain (2003). Shelf water was identified as water with salinity $<34$, representing the water inside the shelf-slope front. Generally, this is the water from the Gulf of Maine and Georges Bank regions that flows southwestward through the Middle Atlantic Bight. The volume of SHW in each region of the Middle Atlantic Bight also was determined on each survey.

Since the survey cruises did not occur at exactly the same time each year, direct comparison between years is confounded by the annual cycle in water properties that occurs in most areas. To allow comparison between years the annual cycle of the hydrographic properties in each area and layer was determined using the data from the MARMAP period, as done by both Smith et al. (2001) and Mountain (2003). The departure from the reference cycle for each survey value represents the anomaly for that property at the time of that survey cruise. The anomalies represent the interannual variability in the various water mass properties. The annual cycles derived from the MARMAP data are a consistent reference against which to compare observations from different years. When anomaly values for each sub-region of the Middle Atlantic Bight were available within a 30-day period, they were combined to derive an anomaly for the Bight as a whole.

\section{Results}

Surface Layer Shelf Water Salinity. The salinity anomalies for the upper layer of the Gulf of Maine and on Georges Bank exhibit variability that is spatially coherent around the region and temporally coherent on a multiyear time scale (Fig. 4). The major feature during the $1990 \mathrm{~s}$ is a freshening by about 0.5 in salinity relative to the earlier decade.

Within the Middle Atlantic Bight the SHW salinity variability was very similar to that in the Gulf of Maine and Georges Bank region (Fig. 5). This result is not surprising since largely the SHW in the Middle Atlantic Bight is the same water that flows around the Gulf and Georges Bank. Local freshwater input, through direct precipitation and river inflows, did contribute to the salinity variability in the Middle Atlantic Bight, but not as a major factor Mountain (2003).

Surface Layer Shelf Water Temperature. SHW in Middle Atlantic Bight experienced considerable temperature variability, with anomalies ranging from $<-1^{\circ} \mathrm{C}$ to about $+3^{\circ} \mathrm{C}$ (Fig. 5). The 1990 s generally were warm compared to the MARMAP reference period, with an average anomaly of about $+1^{\circ} \mathrm{C}$. Averaging 


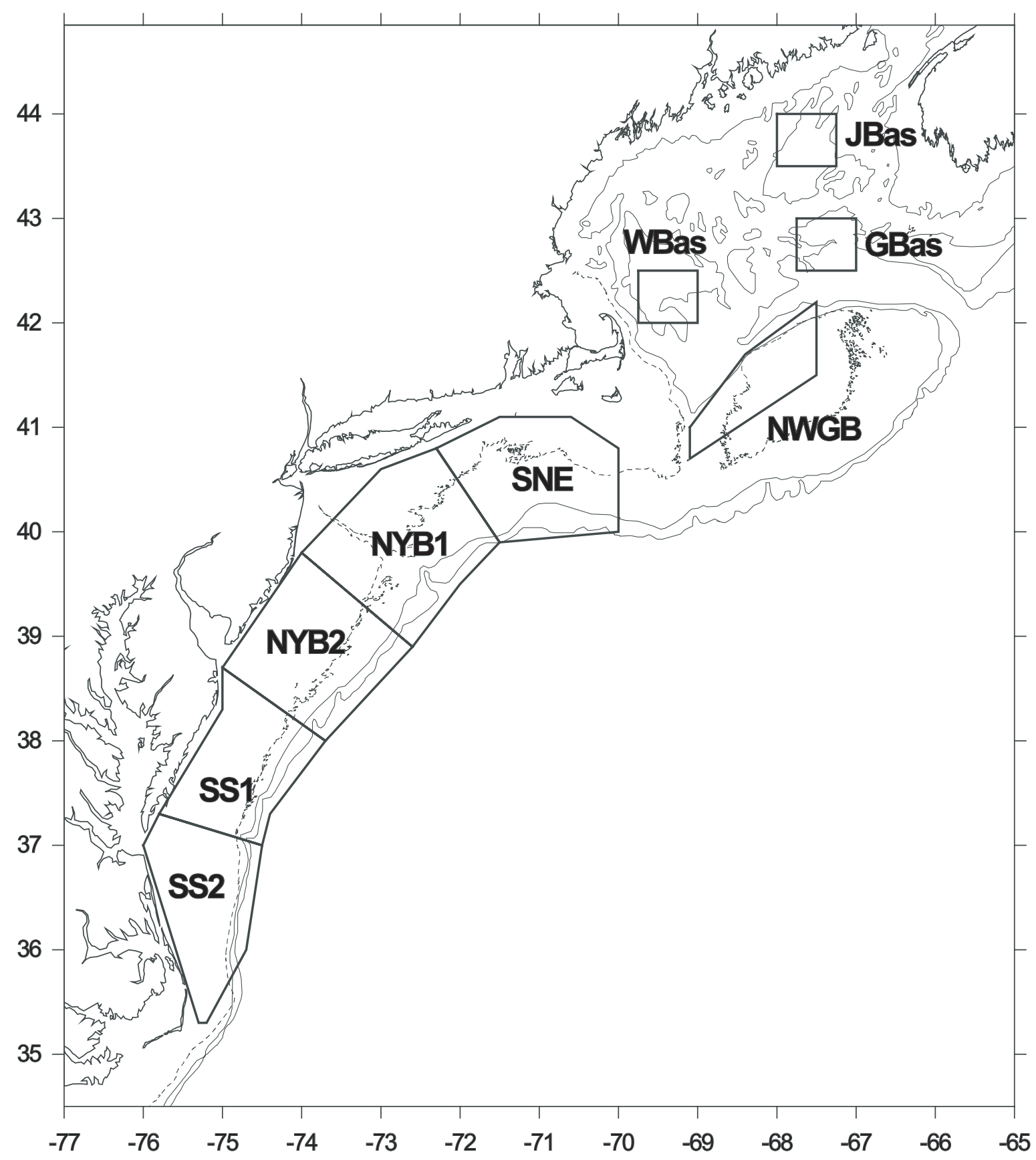

Fig. 3. Sub-regions of the northeast USA continental shelf region.

the anomalies during the 1990s within the different sub-regions of the Middle Atlantic Bight (Fig. 3) and within three periods of the year reveals a strong spatial and seasonal pattern to the temperature anomalies (Fig. 6). During the winter and early spring (first third of the year), the anomalies in the southern parts of the shelf were quite warm. The anomalies decreased progressively northward to be negative in the surface layers of the basins in the Gulf of Maine (Fig. 7). During the middle third of the year the pattern was reversed, with negative anomalies to the south and generally positive anomalies to the north. In the last third of the year, the temperature anomalies were not significant, being slightly negative in the Gulf of Maine and slightly positive in the other regions.

Volume of SHW in Middle Atlantic Bight. The amount of Scotian Shelf water in the Middle Atlantic Bight also exhibited large inter-annual variability (Fig. 


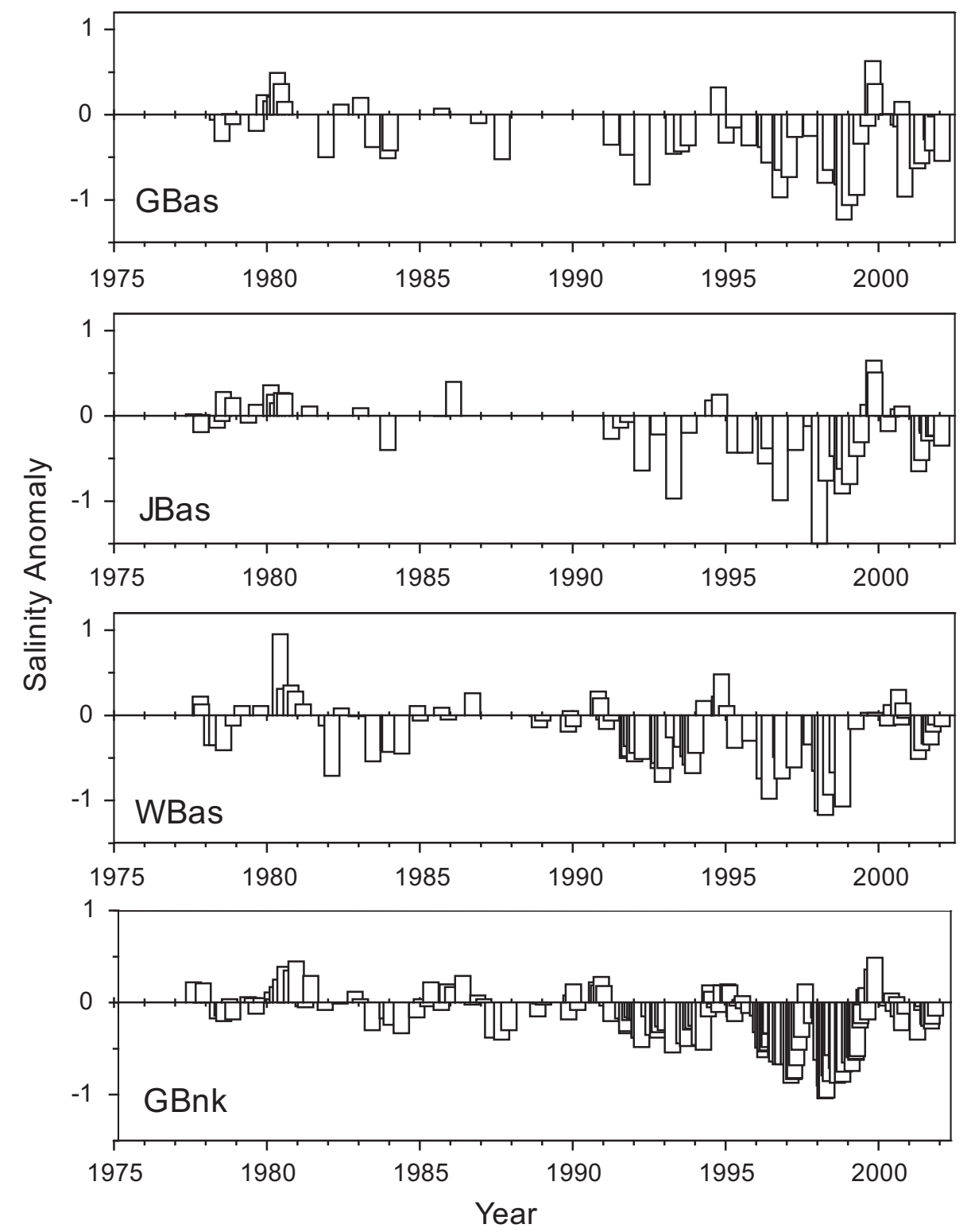

Fig. 4. Salinity anomalies for the surface layer (0-30 m) of Georges Basin (GBas), Jordan Basin (JBas), Wilkinson Basin (WBas) and northwestern Georges Bank (GBnk).

5). The range in the anomalies from about $-1500 \mathrm{~km}^{3}$ to $2000 \mathrm{~km}^{3}$ is almost equal to the $4000 \mathrm{~km}^{3}$ mean volume of SHW in the Middle Atlantic Bight. During the 1990s, the SHW volume was on average about $1000 \mathrm{~km}^{3}$ greater than in the earlier decade. The volume and salinity variability exhibits a strong inverse relationship throughout the whole time series.

Deep Layer Properties in the Gulfof Maine. Annual cycles of temperature, derived from data during the MARMAP period, show that the deeper layer
(150-200 m) of the eastern Gulf (Jordan and Georges Basins) is considerably warmer than that in the western Gulf (Wilkinson Basin) (Fig. 8). During the 1990s, the deep water in Georges Basin was generally warmer than the annual cycle (Fig. 9). The four observations that were cooler were all from 1998. The temperature and salinity anomalies of the Georges Basin deep waters during the 1990s lie along a line with a slope equal to that of the mixing line between SSW and SLW (Fig. 10). This suggests that much of the variability in the water mass properties result from changes in the ratio of the different 

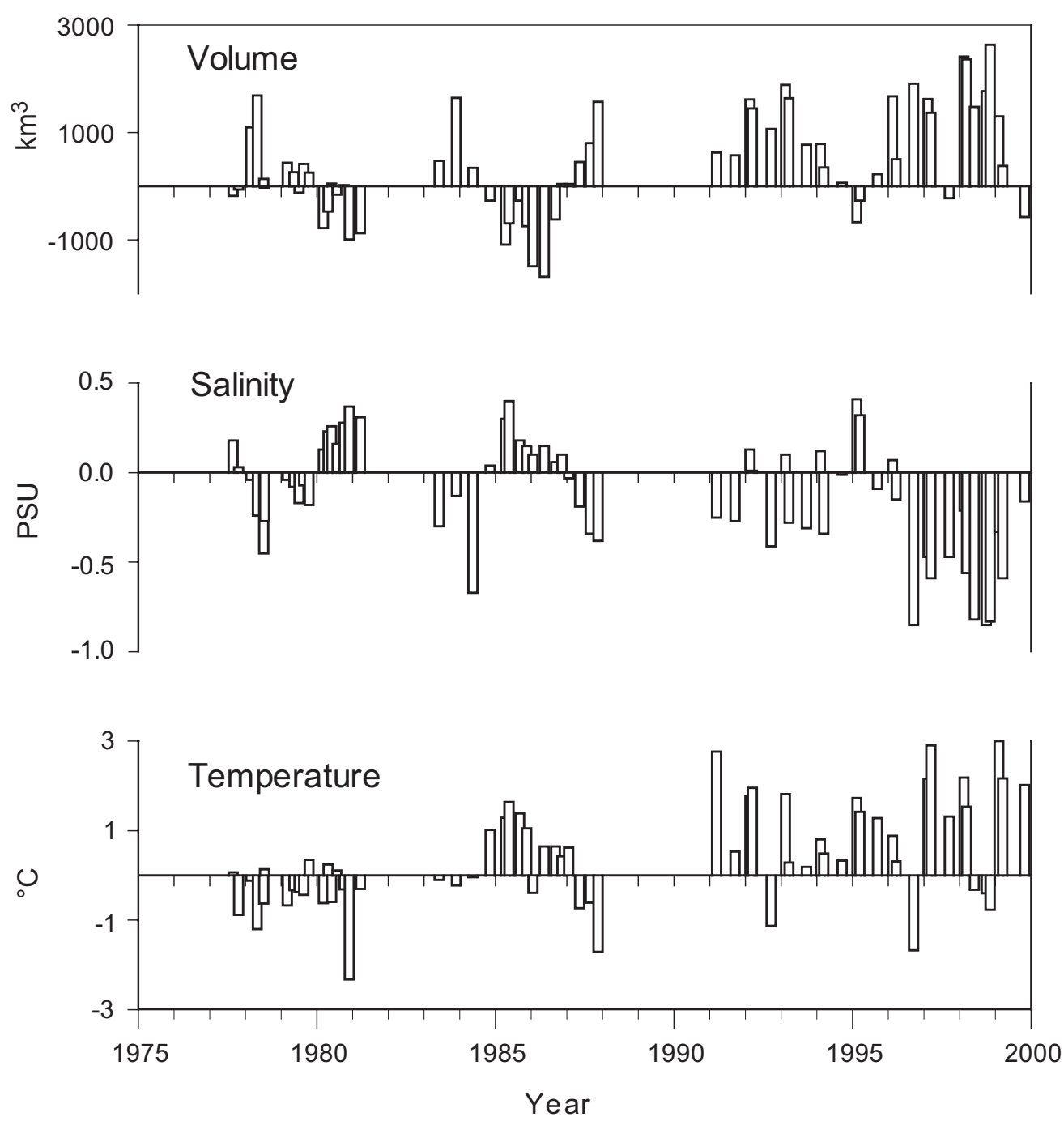

Fig. 5. Anomalies for Shelf Water volume, salinity and temperature in the Middle Atlantic Bight.

source waters. In addition, during the 1990s at any observed salinity the Georges Basin deep water appears to have been about $0.5^{\circ} \mathrm{C}$ warmer than the reference period. In Wilkinson Basin, the deep-water temperatures in the 1990s were all warmer than the annual cycle (Fig. 11). While the MARMAP period exhibited a significant decrease in temperature from January into April, no general winter cooling of the deep waters was evident in the 1990s.

The cool temperatures in the Georges Basin deep water during 1998 resulted from a change in characteristics of the Slope Water entering the Gulf of Maine. Drinkwater et al. (2002) documented the westward extension of the Labrador Slope Water (LSW) during 1997 along the Scotian Shelf and into the Gulf of Maine in early 1998. The LSW which was a few degrees cooler than the warmer slope water it replaced, was evident in the Gulf through 1998, but was gone by the beginning of 1999 .

\section{Discussion}

The 1990s were characterized by low salinities in the surface layers of the Gulf of Maine and throughout the Middle Atlantic Bight. Smith et al. (2001) identified this freshening and attributed it to changes in the inflows to the Gulf of Maine. Measurements of SSW inflow around Cape Sable and of the SLW inflow through the Northeast Channel were made in the late 1970s by Smith (1983) and by Ramp et al. (1985), respectively. The mean SSW inflow was $0.14 \times 10^{6} \mathrm{~m}^{3} \mathrm{~s}^{-1}$ and the mean SLW inflow was $0.26 \times 10^{6} \mathrm{~m}^{3} \mathrm{~s}^{-1}$. Comparable current meter measurements in the mid-1990s indicated $0.30 \times 10^{6} \mathrm{~m}^{3} \mathrm{~s}^{-1}$ for the SSW inflow (Ramp et al., 1985) and $0.14 \times 10^{6} \mathrm{~m}^{3} \mathrm{~s}^{-1}$ for the SLW 


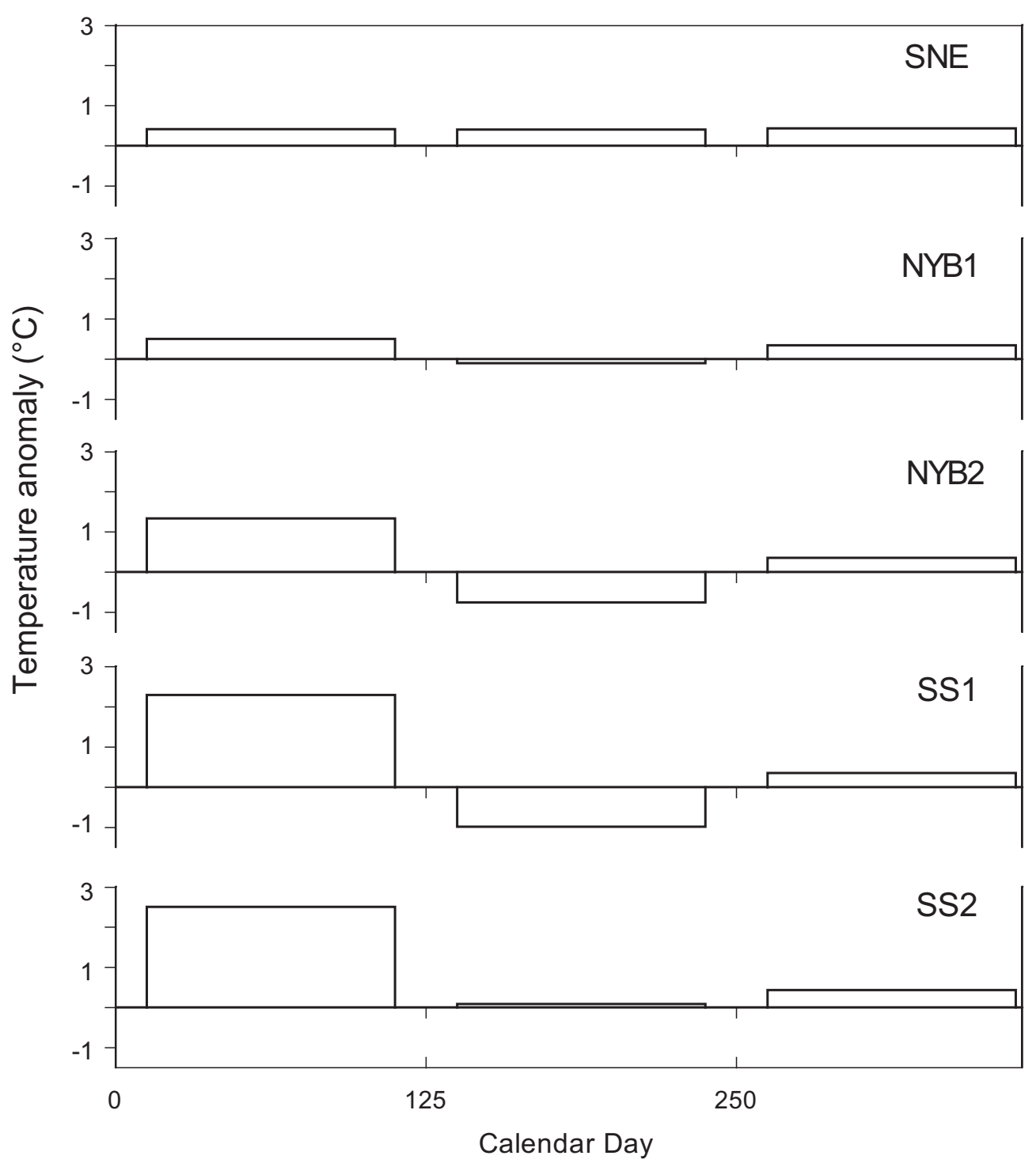

Fig. 6. Average temperature anomalies for Shelf Water in sub-regions of the Middle Atlantic Bight (see Fig. 3) during the 1990 s during three periods of the year.

inflow (Smith, 1983). While the total inflow during the two periods was about the same, the relative contributions by the two inflows were reversed. The lowering of the salinity in the 1990s relative to the 1978-87 levels is attributed to greater SSW inflow during the 1990s. In addition, near surface salinities on the Scotian Shelf were the lowest on record in the 1990s (Drinkwater et $a l ., 2003)$. The changes in the inflows also might have affected the nutrient concentrations and the amount and species of plankton advected into the Gulf. Such changes could have implications for the productivity at the lower trophic levels. Subsequent analyses would be needed to investigate those possibilities.
Mountain (2003) showed that changes in the SHW volume in the Middle Atlantic Bight during the 1990s were very similar to changes in the volume transport into the Gulf of Maine in the measurements reported by Smith et al. (2001). Mountain (2003) concluded that the changes in the inflows to the Gulf system were the primary cause not only of the salinity variability throughout the region, but also of the changes in the volume of SHW in the Middle Atlantic Bight, at least on an inter-annual time scale. On a decadal scale, the cause for the approximate $1000 \mathrm{~km}^{3}$ increase in SHW volume during the 1990s relative to the MARMAP reference period was not obvious since, as indicated above, the net inflow to the Gulf of Maine 


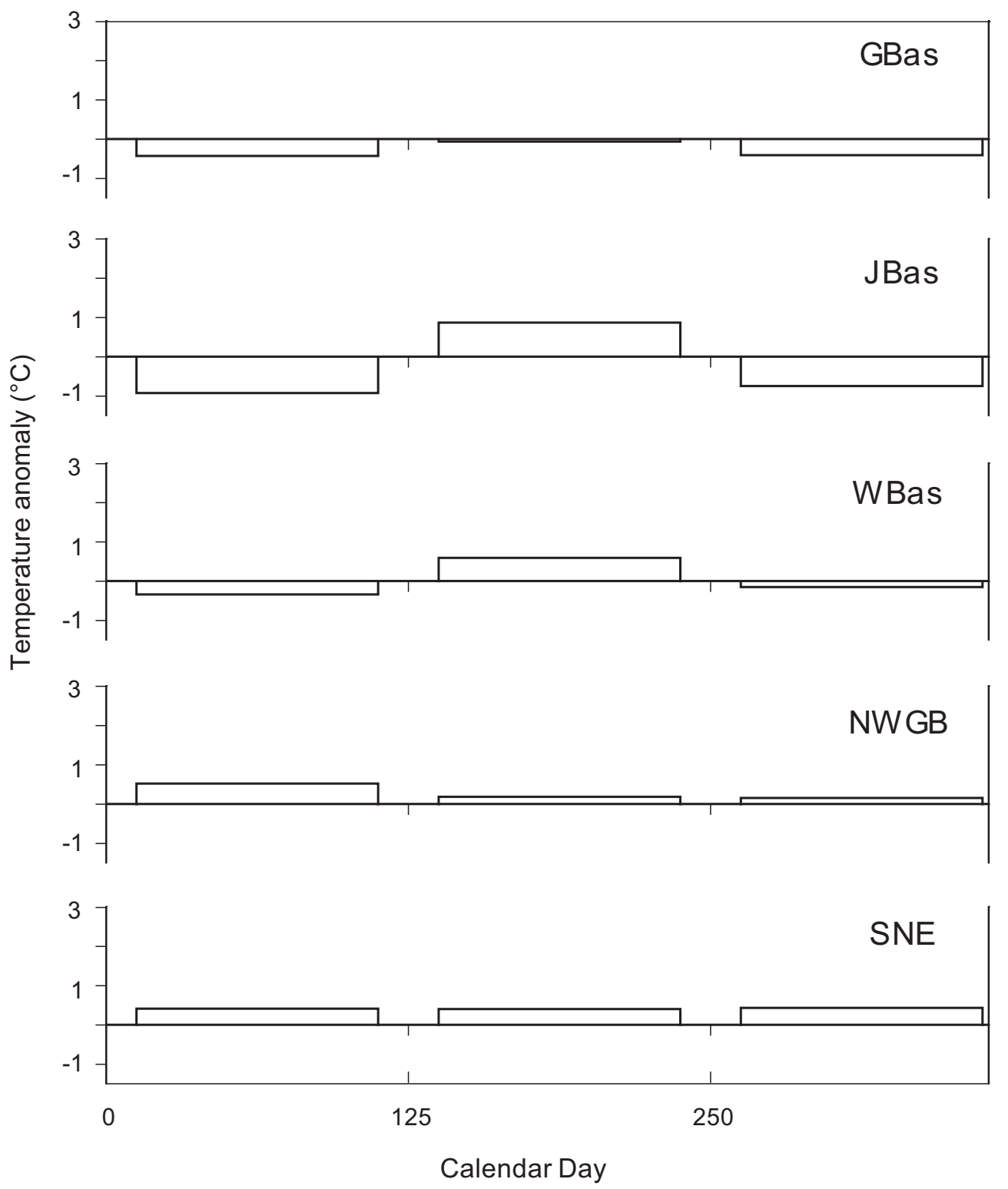

Fig. 7. Average temperature anomalies for the surface layer $(0-30 \mathrm{~m})$ in regions of the Gulf of Maine and Georges Bank (see Fig. 3) during the 1990s during three periods of the year.

was about the same in the two periods. Regardless of the cause, the changes in the location of the shelf/slope front associated with changes in the SHW volume in the Middle Atlantic Bight may also have important implications for local living marine resources. This would be particularly true for the bivalve populations that reside on the outer shelf in the Middle Atlantic Bight as movement of the front could change the water mass properties overlying the animals, with accompanying changes in the temperature and planktonic prey organisms.

The temperature changes during the 1990s suggest greater local surface heat flux (or less cooling) during the winter on the southern part of the shelf compared to the northern regions. The progressive, northward decrease in winter warming likely was due to a comparable decrease in surface heat flux. Alternatively, the greater inflow of SSW into the surface layers of the Gulf of Maine would be expected to have caused cooler surface layer water temperatures. The surface layer temperature changes in winter may have resulted from a combination of greater surface heat flux throughout the region and an advective cooling from the north. A detailed, quantitative analysis of the surface and advective heat fluxes would be needed to assess the relative importance of their contributions to the observed temperature changes. 


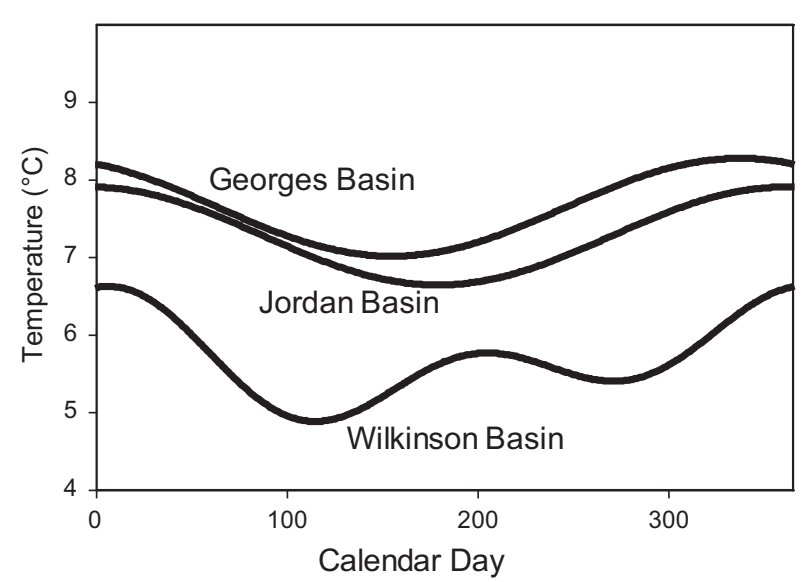

Fig. 8. The annual cycle of temperature in the deep layer (150-200 m) of Georges Basin, Jordan Basin and Wilkinson Basin in the Gulf of Maine.

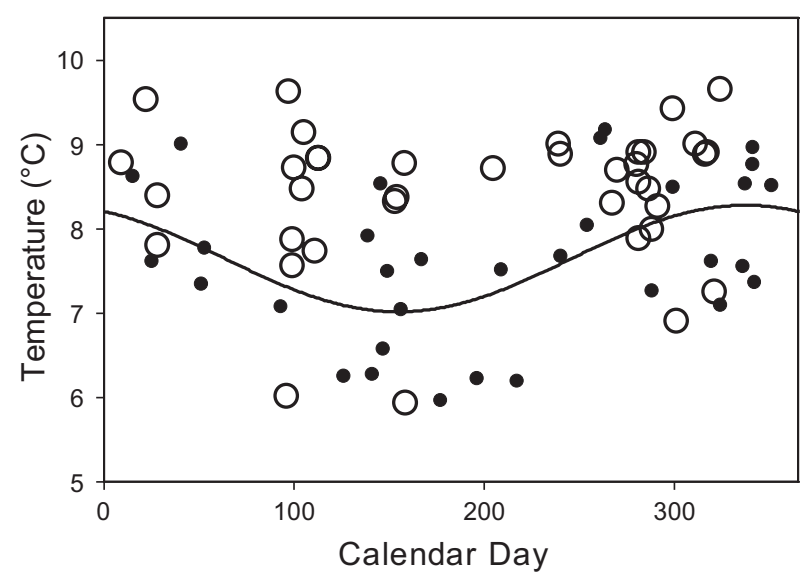

Fig. 9. Deep layer (150-200 m) temperature in Georges Basin from surveys during the 1990s (open circles) and during the MARMAP period (filled circles). The annual cycle for the temperature is indicated by the solid line.

The deep waters in the western Gulf of Maine are characteristically cooler than those found in the eastern Gulf because of greater winter convection. As shown by Mountain and Jessen (1983) and Mountain and Manning (1994) higher surface layer salinities in the western Gulf during winter results in deeper convective mixing that cools the deep waters. During a number of years in the 1990s the deep waters of the western Gulf did not exhibit a significant winter cooling, but instead remained relatively warm. The lack of cooling was likely due to lower surface layer salinities (e.g., Fig. 4) which increased the stratification thus inhibiting deep wintertime convection. Reduced atmospheric cooling (increased surface heat flux), as suggested above in relation to the

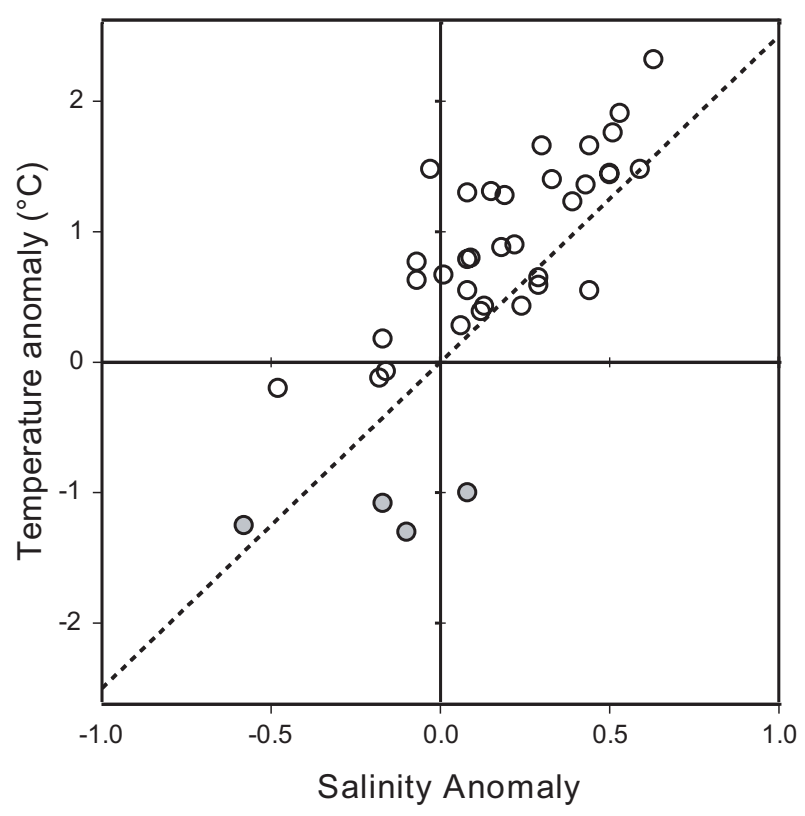

Fig.10. Anomalies of deep layer (150-200 m) temperature and salinity in Georges Basin from surveys during the 1990s. The filled circles are observations from 1998. The mixing curve between Scotian Shelf Water and Slope Water (see Fig. 2) is indicated by the dashed line.

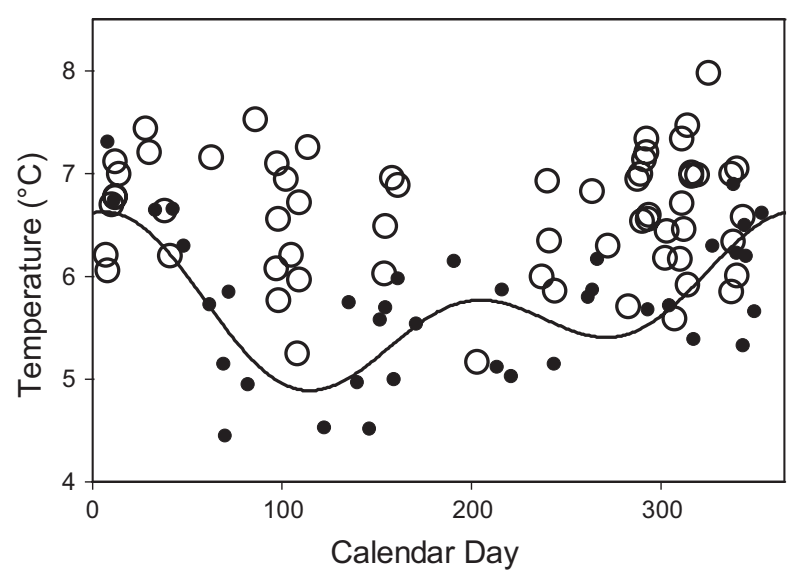

Fig. 11. Deep layer $(150-200 \mathrm{~m})$ temperature in Wilkinson Basin from surveys during the 1990s (open circles) and during the MARMAP period (filled circles). The annual cycle for the temperature is indicated by the solid line.

surface layer temperatures throughout the region, also may have contributed to the reduced convection. Again, a more detailed analysis will be needed to quantitatively determine the cause of the deep temperature changes. The warmer bottom temperatures in the western Gulf of Maine during the 1990s might have had important implications 
for the benthic community and for temperature sensitive marine species in the region, such as northern shrimp (Pandalus borealis).

The ability to compare the various water mass property values presented here (i.e., 1970s-90s) with those in earlier decades is limited by the lack of routine, region-wide sampling prior to the mid-1970s. This limitation is particularly true in the Middle Atlantic Bight where salinity data is critical for differentiating between SHW and SLW. Temperature measurements made in connection with the NMFS trawl survey program that began in 1963 show that the mid-to-late 1960s were quite cold throughout the region relative to the MARMAP reference period (Holzwarth and Mountain, 1992). Petrie and Drinkwater (1993) showed that the cold conditions in the Gulf of Maine during the late 1960s were due to the influx of Labrador Slope Water into the region. Taylor and Mountain (2003) showed that the cold conditions in the northern Middle Atlantic Bight during the same period were due primarily to more intense local winter cooling. Coastal water temperature time records from the Gulf of Maine indicate that the 1950s was the warmest recent decade, while the decade of the 1940s was at least as cold as the 1960s (Petrie and Drinkwater, 1993).

\section{Summary}

During the 1990s, the salinity of surface waters in the Gulf of Maine region and the shelf water in the Middle Atlantic Bight was lower than that during the MARMAP period of 1978-87. An increased inflow of low salinity water from the Scotian Shelf into the Gulf of Maine is believed to be the primary cause of the salinity changes throughout the region.

The volume of Shelf Water in the Middle Atlantic Bight was about $1000 \mathrm{~km}^{3}$ larger on average during the 1990s compared with the previous decade. The cause of this decadal change is not known.

Changes in the surface layer and Shelf Water temperature relative to the previous decade exhibited a spatial and seasonal pattern, marked particularly by warmer conditions during the winter in the southern Middle Atlantic Bight. The temperature variability was most likely caused by a combination of variations in the local atmospheric surface heat flux coupled with changes in the advective heat flux associated with advection into the Gulf of Maine system.

The deep waters of the western Gulf of Maine were significantly warmer in the 1990s compared to the previous decade. This increase is believed due to reduced wintertime convective cooling that caused changes in the stratification associated with the lower surface layer salinities in the Gulf of Maine.

\section{References}

BIGELOW, H. B. 1927. Physical oceanography in the Gulf of Maine. Bulletin of the U.S. Bureau of Fisheries, 40: $511-1027$.

BIGELOW, H. B., and M. SEARS. 1935. Studies of the waters on the continental shelf, Cape Cod to Chesapeake Bay. II. Salinity. Papers in Physical Oceanography and Meteorology, 4: $94 \mathrm{p}$.

BROWN, W. S., and J. D. IRISH. 1993. The annual variation in water mass structure in the Gulf of Maine: 1986-1987. J. Mar. Research, 51: 53-107.

DRINKWATER, K. F., D. G. MOUNTAIN, and A. HERMAN. 2003. Variability in the slope water properties off eastern North America and their effects on the adjacent shelves. $J$. Geophys. Res., (submitted).

DRINKWATER, K. F., B. PETRIE, and P. C. SMITH. 2003. Climate variability on the Scotian Shelf during the 1990s. ICES Mar. Sci. Symp., 219: 40-49.

HOLZWARTH, T., and D. MOUNTAIN. 1992. Surface and bottom temperature distributions from the Northeast Fisheries Science Center spring and fall bottom trawl survey program 1963-1987 with addendum for 1988-1990. NMFS Laboratory Reference Document 90-03, 71.

HOPKINS, T.S., and N. GARFIELD III. 1979. Gulf of Maine intermediate water. J. Mar. Research, 37: 103-139.

1981. Physical origins of Georges Bank water. J. Mar. Research, 39: 465-500.

MANNING, J. 1991. Middle Atlantic Bight salinity: interannual variability. Cont. Shelf Res., 11: 123-137.

MOUNTAIN, D. G. 2003. Variability in the properties of Shelf Water in the Middle Atlantic Bight, 197799. J. Geophys. Res., 108(C1), 3014, doi:10.1029/ 2001JC001044.

MOUNTAIN, D. G., and P. F. JESSEN. 1987. Bottom waters of the Gulf of Maine, 1978-1983. J. Mar. Res. 45: 319-345.

MOUNTAIN, D. G., and J. P. MANNING. 1994. Seasonal and interannual variability in the properties of the surface waters of the Gulf of Maine. Cont. Shelf Res., 14: 1551-1581.

PETRIE, B., and K. DRINKWATER. 1993. Temperature and salinity variability on the Scotian Shelf and in the Gulf of Maine, 1945-1990. J. Geophys. Res., 98: 20079-20089.

RAMP, S. R, R. S. SCHLITZ, and R. WRIGHT. 1985. The deep flow through the Northeast Channel, Gulf of Maine. J. Phys. Oceanogr., 15: 1790-1808.

SMITH, P. C. 1983. The mean and seasonal circulation off southwest Nova Scotia. J. Phys. Oceanogr., 13: 1034-1054.

SMITH, P. C., R. W. HOUGHTON, R. G. FAIRBANKS, and D. G. MOUNTAIN. 2001. Interannual variability of boundary fluxes and water mass properties in the Gulf of Maine and on Georges Bank: 1993-97. Deep Sea Res., 48: 37-70.

TAYLOR, M. H., and D. G. MOUNTAIN. 2003. The role of local wintertime atmospheric heat flux in determining springtime temperature variability in the northern Middle Atlantic Bight during 1965-1973. Cont. Shelf Res., 23: 377-386. 